\title{
PENGARUH MODAL SOSIAL TERHADAP KEBERLANJUTAN GAPOKTAN NGUDI RUKUN DI KABUPATEN WONOGIRI
}

\author{
Tri Ermawati ${ }^{*}$ 1), Tutik Dalmiyatun ${ }^{2)}$, Kadhung Prayoga ${ }^{2)}$ \\ 1) Program Studi Agribisnis Fakultas Peternakan dan Pertanian Universitas Diponegoro, Semarang, \\ Indonesia \\ 2) Fakultas Peternakan dan Pertanian Universitas Diponegoro, Semarang, Indonesia \\ *) E-mail Penulis Korespondensi: triermawati039@gmail.com
}

\begin{abstract}
ABSTRAK
Modal sosial merupakan suatu rangkaian proses hubungan antar manusia yang ditopang oleh jaringan, norma-norma dan kepercayaaan sosial yang memungkinkan efisiensi dan efektifitas koordinasi serta kerjasama untuk keuntungan bersama. Tujuan penelitian adalah untuk menganalisis modal sosial, keberlanjutan, dan pengaruh modal sosial terhadap keberlanjutan Gabungan Kelompok Tani (Gapoktan) Ngudi Rukun di Kabupaten Wonogiri. Penelitian dilaksanakan pada bulan September sampai Oktober 2020. Metode yang digunakan adalah metode kuantitatif. Penentuan sampel menggunakan metode slovin dan diperoleh 82 responden. Pengambilan data dengan melakukan observasi, wawancara, dan dokumentasi. Tehnik analisis data yang digunakan adalah analisis regresi linear berganda. Hasil penelitian menunjukkan bahwa modal sosial yang ada di Gapoktan Ngudi Rukun tergolong dalam kategori tinggi dengan presentase jaringan kerjasama $60 \%$, kepercayaan $48 \%$ dan norma $64 \%$. Tingkat keberlanjutan di Gapoktan Ngudi Rukun termasuk dalam kategori sangat tinggi dengan tingkat presentase $94 \%$. Modal sosial yang terdiri dari jaringan kerjasama, kepercayaan dan norma berpengaruh secara serempak dan parsial terhadap keberlanjutan Gapoktan Ngudi Rukun di Kabupaten Wonogiri. Nilai Adjusted R-Square sebesar 0,919 yang berarti keberlanjutan Gapoktan Ngudi Rukun dipengaruhi oleh modal sosial (jaringan kerjasama, kepercayaan, dan norma) sebesar $91,9 \%$. Modal sosial dalam gapoktan perlu ditingkatkan dalam mengembangkan usaha ekonomi produktif.
\end{abstract}

Kata kunci: Gapoktan; Keberlanjutan; Modal Sosial; Padi.

\section{PENDAHULUAN}

Sektor pertanian merupakan sektor yang berperan penting dalam pembangunan ekonomi nasional. Sektor ini berperan sebagai penyedia kebutuhan pangan masyarakat, pembentukan Pendapatan Domestik Bruto (PDB), menyerap tenaga kerja di desa, menghasilkan devisa dan penghematan devisa, dan berfungsi dalam pengendalian inflasi. Sektor pertanian di Indonesia meliputi subsektor tanaman pangan, holtikultura, perikanan, peternakan, kehutanan dan perkebunan. Subkategori tanaman pangan dan tanaman perkebunan merupakan sukategori yang memberikan kontribusi lebih dari separuh terhadap pembentukan PDB lapangan usaha pertanian, kehutanan dan perikanan. Laju pertumbuhan PDB subkategori tanaman pangan khususnya padi sampai dengan tahun 2017, berada pada triwulan I sebesar 99,58\% (2014), 103,68\% (2015), 94,83\% (2016), dan 91,68\% (2017) (Badan Pusat Statistik, 2018). Pertumbuhan PDB di Indonesia tidak lepas dari sumbangan sektor pertanian.

Tahap awal pembangunan sektor pertanian merupakan penopang perekonomian. Pembangunan pertanian diarahkan untuk meningkatkan produksi pertanian guna 
memenuhi kebutuhan pangan dan industri dalam negeri. Hal ini dikarenakan sektor pertanian adalah satu-satunya sektor yang mampu menyediakan kebutuhan pangan yang mendasar (Hayati et al., 2017). Membangun sektor pertanian yang tangguh dibutuhkan organisasi petani yang berkembang dan memiliki posisi tawar kuat, kelompok tani profesional, penyuluh pertanian swadaya dan swasta menyatu dengan petani. Pencapaian pembangunan pertanian guna mendukung pembangunan nasional dapat dimulai dari tingkat petani di pedesaan, diantaranya adalah usaha tani padi. Salah satu daerah di Indonesia yang merupakan produsen penghasil padi adalah Kecamatan Girimarto, Kabupaten Wonogiri.

Kecamatan Girimarto merupakan salah satu kecamatan di Kabupaten Wonogiri yang menjadikan sektor pertanian sebagai sektor unggulan daerah. Kecamatan Girimarto memiliki luas wilayah 6.236,68 Ha. Hampir seluruh kawasan merupakan kawasan pertanian dengan berbagai jenis pemanfaatan lahan pertanian, seperti pemanfaatan lahan untuk tanaman padi, tanaman jagung, tanaman kacang tanah, ubi kayu dan tanaman pertanian lainnya.

Tabel 1. Hasil Produksi dan Luas Panen Komoditas Pertanian di Kecamatan Girimarto, Kabupaten Wonogiri

\begin{tabular}{|c|c|c|c|}
\hline No. & Komoditas & $\begin{array}{c}\text { Luas Panen } \\
\text {---Ha--- }\end{array}$ & $\begin{array}{c}\text { Produksi } \\
---K w---\end{array}$ \\
\hline 1. & Padi Sawah & 4.207 & 262.459 \\
\hline 2. & Jagung & 998 & 62.631 \\
\hline 3. & Kacang Tanah & 720 & 11.441 \\
\hline 4. & Ubi Kayu & 1.562 & 340.546 \\
\hline
\end{tabular}

Sumber: Kecamatan Girimarto Dalam Angka, 2018.

Desa Doho adalah salah satu desa yang ada di Kecamatan Girimarto yang memiliki potensi pertanian, khususnya tanaman padi. Penduduk di Desa Doho pada umumnya adalah petani yang menggarap sawah sendiri maupun sawah milik orang lain. Pemeliharaan tanaman padi dimulai dari prapanen hingga pasca panen membutuhkan modal yang tidak sedikit serta dibutuhkan adopsi dan inovasi teknologi demi tercapainya hasil yang melimpah dan memperoleh keuntungan lebih. Kelompok tani yang ada di Desa Girimarto, bisa dikatakan belum mampu menjembatani kepentingan petani dalam upaya memperbaiki kinerja usahataninya.

Permasalahan yang terjadi dalam kelompok tani terletak pada pemasaran hasil usahatani yaitu posisi tawar atau harga hasil pertanian menurun saat panen raya tiba. Kecemburuan sosial yang terjadi antar kelompok tani masih belum mampu dipecahkan oleh kelembagaan kelompok tani. Tidak hanya itu petani di Desa Doho juga sering dipermainkan para tengkulak, oleh karena itu untuk mengatasi hal tersebut dibentuklah sebuah gapoktan.

Gabungan Kelompok Tani Ngudi Rukun merupakan salah satu lembaga yang bergerak dibidang pertanian yang berada di Desa Doho, Kecamatan Girimarto dan menaungi tujuh kelompok tani. Kemunculan gapoktan tidak terlepas dari permasalahan mengenai pemeliharaan, produksi, dan pemasaran tanaman pertanian serta kurangnya adopsi teknologi dan informasi. Pembentukan gapoktan ini diharapkan agar mampu untuk menjalin hubungan kerjasama antar kelompok tani, menhindari konflik kepentingan, meningkatkan modal sosial yang dimiliki oleh anggotanya serta mampu menjembatani kinerja petani dalam keberlanjutan suatu kelompok. Gapoktan merupakan media komunikasi untuk saling bertukar informasi antar kelompok tani. Keberadaan gapoktan merupakan sebuah modal sosial yang cukup besar guna membangun kekuatan di tingkat petani.

Modal sosial merupakan suatu rangkaian proses hubungan antar manusia yang di topang oleh jaringan, norma-norma dan kepercayaaan sosial yang memungkinkan 
efisiensi dan efektifitas koordinasi dan kerjasama untuk keuntungan bersama, lebih menekankan pada dimensi yang lebih luas yaitu segala sesuatu yang membuat masyarakat bersekutu untuk mencapai tujuan bersama atas dasar kebersamaan, dan didalamnya diikat nilai-nilai dan norma-norma yang tumbuh dan dipatuhi (Thobias et al., 2013). Modal sosial sangat penting untuk dipahami agar dapat mengetahui bagaimana petani memperoleh informasi mengenai inovasi, menerapkan inovasi, dan memperoleh keuntungan dari inovasi yang diterapkan (Bulu, 2010). Masyarakat yang memiliki nilai modal sosial tinggi cenderung mampu menyelesaikan masalah dengan lebih mudah sehingga masyarakat terbiasa hidup dengan rasa saling mempercayai satu sama lain (Barki, 2017).

Penelitian yang dilakukan Barki (2017) menunjukkan hasil bahwa variabel network, trust dan norm berpengaruh sangat nyata dan secara bersama-sama terhadap tingkat adopsi inovasi padi organik, hanya saja indikator dari tingkat adopsi inovasi tidak dijelaskan. Penelitian yang dilakukan Munawaroh (2017) menjelaskan pada gambaran umum modal sosial, hasil penelitian menunjukkan bahwa ada pengaruh yang positif dan signifikan antara modal sosial terhadap peningkatan kesejahteraan. Lebih lanjut, Tangio (2021) menemukan bahwa adanya peran kepercayaan sosial, norma sosial, dan jaringan sosial dalam proses pengembangan usaha agroindustri gula aren. Penelitian ini penulis menganalisis modal sosial, keberlanjutan, dan pengaruh modal sosial terhadap keberlanjutan Gapoktan Ngudi Rukun di Desa Doho, Kecamatan Girimarto, Kabupaten Wonogiri. Indikator modal sosial yang ada di penelitian ini adalah jaringan kerjasama, kepercayaan dan norma, sedangkan indikator keberlanjutan gapoktan di penelitian ini adalah kohesivitas, komitmen, program kerja dan interdependensi positif.

Tujuan dari penelitian ini adalah menganalisis modal sosial, keberlanjutan gabungan kelompok tani Ngudi Rukun, dan menganalisis pengaruh modal sosial terhadap

keberlanjutan Gabungan Kelompok Tani Ngudi Rukun di Desa Doho, Kecamatan Girimarto, Kabupaten Wonogiri.

\section{METODE}

Metode penelitian yang digunakan adalah metode kuantitatif. Penelitian dilaksanakan pada bulan September sampai Oktober 2020 terhadap Gabungan Kelompok Tani Ngudi Rukun yang berlokasi di Desa Doho, Kecamatan Girimarto, Kabupaten Wonogiri. Penentuan lokasi dilakukan dengan metode purposive sampling dengan pertimbangan Gapoktan Ngudi Rukun merupakan satu-satunya gapoktan yang aktif di Kecamatan Girimarto. Penentuan sampel menggunakan metode Slovin dan diperoleh responden berjumlah 82 orang. Metode pengambilan data yang digunakan dalam penelitiam ini adalah observasi, wawancara dan dokumentasi.

Observasi dilakukan dengan peneliti datang langsung ke lokasi penelitian yaitu Gabungan Kelompok Tani Ngudi Rukun yang berada di Desa Doho, Kecamatan Girimarto, Kabupaten Wonogiri. Wawancara dilakukan dengan anggota gapoktan secara langsung. Peneliti datang ke rumah responden sesuai arahan dari ketua kelompok tani masing-masing. Dokumentasi dilakukan dengan mengambil foto antara peneliti dan responden, foto gudang gapoktan, foto perkumpulan gapoktan dan lainnya sebagai bukti telah melaksanakan penelitian.

Data yang di ambil dalam penelitian ini adalah data primer dan data sekunder. Data primer diperoleh dari hasil wawancara dengan 82 responden berupa identitas responden, karakteristik responden, dan kegiatan kelompok. Data sekunder diperoleh dari profil Gapoktan Ngudi Rukun, buku metode penelitian, kondisi geografis Desa Doho, data BPS, jurnal pertanian, dan sebagainya.

Data yang terkumpul dianalisis dengan analisis regresi linear berganda yang sebelumnya dilakukakan uji prasyarat meliputi uji kuesioner, uji normalitas, dan uji asumsi klasik. Persamaan analisis regresi linear berganda yang digunakan adalah: 


$$
Y=\alpha+\beta_{1} X_{1}+\beta_{2} X_{2}+\beta_{3} X_{3}+e
$$

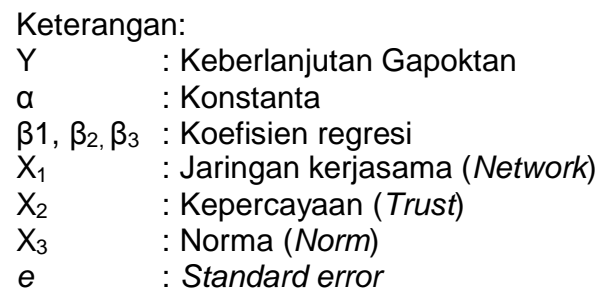

\section{HASIL DAN PEMBAHASAN}

\section{Profil Gabungan Kelompok Tani Ngudi Rukun}

Gabungan Kelompok Tani Ngudi Rukun merupakan gapoktan yang berada di wilayah Desa Doho, Kecamatan Girimarto, Kabupaten Wonogiri. Pembentukan gapoktan di Desa Doho dimaksudkan untuk memenuhi kebutuhan pangan dan kesejahteraan petani, meningkatkan dan menstabilkan harga jual hasil pertanian, penyediaan cadangan pangan dan pendistribusian pangan. Awal mula pembentukan dari Gapoktan Ngudi Rukun dikarenakan adanya rasa prihatin terhadap para petani. Dibentuknya gapoktan juga diharapkan mampu untuk menjalin kerjasama antar anggota kelompok tani.

Gapoktan Ngudi Rukun terdiri dari tujuh kelompok tani dengan jumlah anggota sebanyak 479 petani, terdiri dari 393 petani laki-laki dan 86 petani perempuan. Komoditas yang dikelola oleh Gapoktan Ngudi Rukun adalah tanaman padi, jagung, dan kacang tanah. Komoditas yang unggul adalah tanaman padi.

\section{Identitas Responden}

Responden yang digunakan dalam penelitian ini berjumlah 82 orang yang terbagi atas tujuh anggota kelompok tani yang tergabung dalam Gapoktan Ngudi Rukun di Desa Doho. Karakteristik petani responden yang ditinjau berdsarkan usia, pekerjaan, luas kepemilikan lahan, pendidikan, lama berusahatani, dan status dalam kelompok tani disajikan pada Tabel 2.

Berdasarkan Tabel 2 diketahui hampir keseluruhan usia responden yang tergabung dalam Gapoktan Ngudi Rukun termasuk dalam usia produktif. Usia produktif untuk bekerja menurut BPS (2014) berada pada rentang usia 15 - 64 tahun. Usia mempengaruhi perilaku petani dalam mengambil keputusan, sehingga dapat memudahkan dalam memperoleh, menerima dan menerapkan inovasi yang diberikan penyuluh melalui kelompok tani. Usia yang produktif berhubungan dengan kemampuan kerja petani dalam mengembangkan dan meningkatkan produksi usahatani secara maksimal di dalam sebuah gapoktan. Hal ini sesuai dengan pendapat Palabiran (2015) yang menyatakan bahwa usia seseorang dapat berpengaruh terhadap produktivitas kerja, sebab usia erat kaitannya dengan kemampuan kerja serta pola pikir dalam menentukan manajemen yang diterapkan dalam usaha.

Sebagian besar responden yang tergabung dalam Gapoktan Ngudi Rukun memiliki pekerjaan utama sebagai petani (83\%). Responden yang bekerja disektor non petanian mereka bekerja sebagai perangkat desa, guru dan wiraswasta. Pekerjaan merupakan tolak ukur untuk menentukan tingkat kesejahteraan. Luas lahan yang dimiliki responden diatas 2500 ha sebanyak 56 orang (69\%). Luas lahan pertanian berpengaruh terhadap skala usaha dan mempengaruhi efisien atau tidaknya suatu usaha pertanian. Petani yang memiliki lahan luas akan lebih mudah menerapkan inovasi serta memiliki hasil produksi lebih tinggi. Peningkatan produksi mampu meningkatkan perekonomian dikangan anggota gapoktan.

Pendidikan terakhir yang ditempuh anggota Gapoktan Ngudi Rukun mayoritas adalah lulusan SD (55\%). Hal ini menunjukkan bahwa tingkat pendidikan responden yang tergabung di dalam Gapoktan Ngudi Rukun masih tergolong rendah. Tingkat pendidikan yang rendah belum tentu mencerminkan kinerja yang buruk. Meskipun pendidikan 
anggota tergolong rendah Gapoktan Ngudi Rukun mampu membuktikan kelompoknya sebagai pelaku pembangunan ketahanan pangan bidang Lembaga Distribusi Pangan Masyarakat (LDPM) di Kabupaten Wonogiri.

Tabel 2. Identitas Responden di Gabungan Kelompok Tani Ngudi Rukun

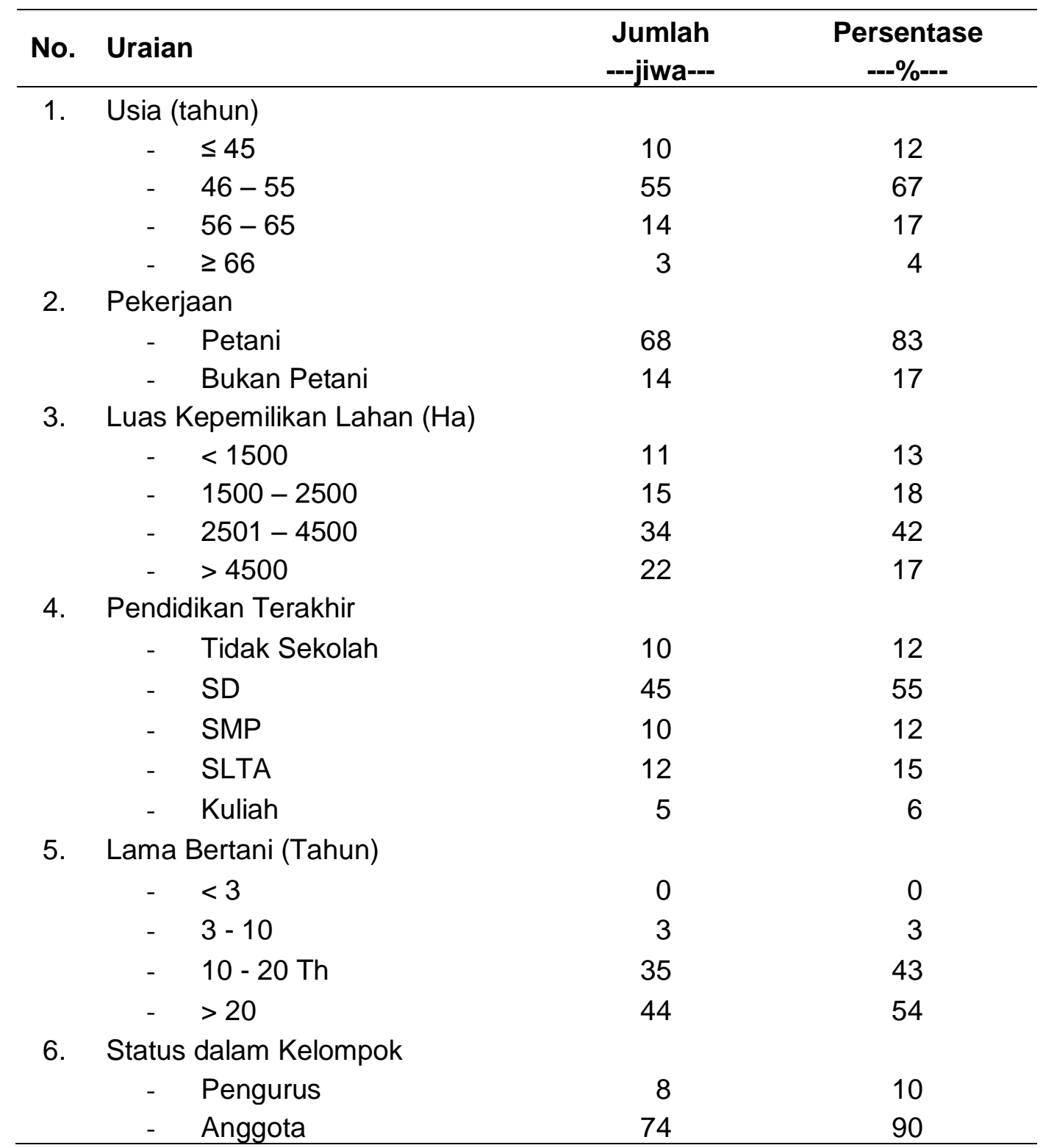

Sumber: Data primer diolah, 2021

Tingkat pendidikan akan berpengaruh terhadap keterampilan petani dalam mengembangkan kegiatan usahatani. Semakin tinggi tingkat pendidikan petani maka kinerja petani juga akan meninggkat sehingga akan meningkatkan produksitivitas yang bagus. Pendidikan petani tidak hanya berorientasi terhadap peningkatan produksi tetapi mengenai kehidupan sosial masyarakat tani di dalam gapoktan. Hal ini didukung dengan pendapat Damayanti (2013) yang menyatakan bahwa tingkat pendidikan petani padi sawah umumnya mempengaruhi cara berfikir mereka, semakin tinggi tingkat pendidikan baik formal maupun non formal diharapkan semakin memiliki kemampuan berfikir lebih rasional dalam mengelola usahanya.

Anggota Gapoktan Ngudi Rukun memiliki pengalaman bertani diatas 10 tahun yaitu sebanyak 79 orang $(97 \%)$ dari 82 orang responden. Petani yang sudah lama berusaha tani memiliki tingkat pengetahuan, pengalaman dan keterampilan yang tinggi dalam 
menjalankan usahataninya. Pengalaman bertani berpengaruh terhadap tingkat pengetahuan petani yang tergabung di Gapoktan Ngudi Rukun dalam pelaksanaan kegiatan usahatani. Anggota Gapoktan Ngudi Rukun memiliki pengalaman dalam bertani cukup lama, sehingga mampu mempengaruhi sikap petani dalam proses penerimaan informasi yang diberikan penyuluh melalui kelompok tani. Hal ini didukung oleh pendapat Fadhillah (2018) yang menyatakan bahwa petani yang sudah lebih lama bertani memiliki pengalaman yang lebih banyak daripada pemula, sehingga dapat mengambil keputusan terhadap anjuran yang diberikan oleh penyuluh. Kedudukan responden dikategorikan sebagai pengurus, anggota dan bukan anggota gapoktan. Sebagian besar responden yang tergabung dalam gapoktan berstatus sebagai anggota Gapoktan Ngudi Rukun yaitu sebanyak 74 orang $(90 \%)$ dari 82 orang responden.

\section{Modal Sosial dalam Keberlanjutan Gapoktan Ngudi Rukun}

Modal sosial penting untuk dipahami agar mengetahui bagaimana petani mampu memperoleh, mengenal, menerima dan menerapkan informasi yang diperoleh untuk keberlanjutan suatu gapoktan. Modal sosial yang berada di Gapoktan Ngudi Rukun dapat diketahui melalui indikator-indikator yang ada dalam modal sosial, yaitu jaringan (network), rasa kepercayaan (trust) dan norma (norm).

Jaringan Kerjasama. Jaringan kerjasama merupakan salah satu indikator yang ada di dalam modal sosial. Jaringan kerjasama memfasilitasi terjadinya komunikasi dan interaksi, memungkinkan tumbuhnya kepercayaan dan memperkuat kerjasama antar manusia. Tingkat presentase jaringan kerjasama yang ada di Gapoktan Ngudi Rukun dapat dilihat pada Tabel 3.

Tabel 3. Presentase Jaringan Kerjasama Berdasarkan Kategori

\begin{tabular}{clccc}
\hline No. & Kategori & Interval Skor & $\begin{array}{c}\text { Frekuensi } \\
\text {--- orang --- }\end{array}$ & $\begin{array}{c}\text { Persentase } \\
\text {---\%--- }\end{array}$ \\
\hline 1. & Sangat Tinggi & $>60$ & 12 & 15 \\
2. & Tinggi & $46-60$ & 49 & 60 \\
3. & Sedang & $31-45$ & 20 & 24 \\
4. & Rendah & $16-30$ & 1 & 1 \\
5. & Sangat Rendah & $<16$ & 0 & 0 \\
\hline & & & $\mathbf{8 2}$ & $\mathbf{1 0 0}$ \\
\hline
\end{tabular}

Sumber: Data primer diolah, 2021

Berdasarkan hasil penelitian didapat bahwa tingkat jaringan kerjasama dalam Gapoktan Ngudi Rukun termasuk dalam kategori tinggi dengan tingkat presentase 60\%. Tingginya kerjasama yang terjalin antara anggota Gapoktan Ngudi Rukun dilihat dari kegiatan pengolahan tanah, penanaman, pemupukan dan pemeliharaan, panen, pasca panen, pembuatan pupuk kompos, penyuluhan dan memperoleh pinjaman modal. Kerjasama yang dilakukan petani dalam pengolahan lahan berupa kegiatan pada saat mencangkul dan membajak sawah, menanam padi, dan memanen hasil pertanian. Hubungan kerjasama yang terjadi antara petani menimbulkan suatu hubungan yang harmonis di dalam gapoktan. Kegiatan pemupukan, pemeliharaan tanaman dan pengolahan hasil pasca panen umumnya dilakukan secara individu oleh petani karena tidak membutuhkan tenaga bantuan dari orang lain.

Anggota gapoktan secara aktif melibatkan diri dalam jaringan sosial sehingga menciptakan suatu hubungan yang harmonis antar anggota. Semua anggota yang tergabung di dalam Gapoktan Ngudi Rukun tergolong aktif. Keaktifan anggota Gapoktan Ngudi Rukun dilihat dari kehadiran anggota dalam kegiatan gapoktan seperti pertemuan rutin, arisan cobak, dan kegiatan lain. Anggota yang tidak aktif adalah petani yang sudah meninggal atau petani yang pindah tempat dan merantau. Anggota gapoktan melakukan 
kegiatan kolektif terhadap usahatani pada saat masa panen tiba. Kegiatan panen dilakukan secara gotong royong dimulai dari kegiatan memotong padi, mengangkut padi, hingga proses perontokan padi. Jaringan yang kuat akan memperkuat kerjasama antar anggota maupun kelompok secara efisien. Hal ini sesuai pendapat Mawardi (2007) yang menyatakan setiap jaringan memiliki nilai-nilai bersama memungkinkan terjadinya aksi bersama yang dilakukan secara efektif dan efisien.

Anggota Gapoktan Ngudi Rukun bekerjasama dengan tim penyuluh pertanian. Tim penyuluh dihadirkan oleh gapoktan untuk memberikan informasi, wawasan dalam berusahatani, adopsi inovasi, perkembangan teknologi pertanian dan pelatihan-pelatihan. Kegiatan penyuluhan berlangsung sebulan sekali. Anggota gapoktan memiliki kegiatan bersama dalam pemenuhan saprodi yaitu pembuatan pupuk kompos dan pupuk cair. Pembuatan pupuk dilakukan secara bersamaan antar anggota kelompok tani. Pembuatan pupuk dilakukan di rumah salah satu anggota gapoktan. Selain kerjasama antar anggota kelompok tani dan tim penyuluh, anggota Gapoktan Ngudi Rukun juga bekerjasama dengan pihak luar yaitu bumdes dan toko tani sebagai penyedia atau suplaiyer beras. Kinerja yang baik antara pengurus gapoktan, anggota gapoktan dan tim penyuluh akan menciptakan hubungan yang selaras.

Gapoktan Ngudi Rukun sering mengikuti kegiatan yang berhubungan dengan ketahanan pangan. Penjualan hasil usaha dilakukan secara bersama-sama antar kelompok tani ke gapoktan. Petani yang tergabung di dalam Gapoktan Ngudi Rukun cenderung tidak melakukan pinjaman modal apabila tidak terjadi kebutuhan yang mendesak.

Kepercayaan. Kepercayaan sebagai salah satu indikator modal sosial yang merupakan bentuk saling percaya diantara pengurus dan anggota kelompok yang tergabung dalam Gapoktan Ngudi Rukun. Tingkat presentase kepercayaan dapat dilihat pada Tabel 4.

Berdasarkan hasil penelitian didapat bahwa tingkat kepercayaan yang terdapat di Gabungan Ngudi Rukun termasuk dalam kategori tinggi dengan tingkat presentase $48 \%$. Kepercayaan dikalangan anggota Gapoktan Ngudi Rukun meliputi kepercayaan pada pengurus dan antar anggota. Tingkat kepercayaan yang terdapat di Gapoktan Ngudi Rukun berupa rasa percaya anggota terhadap pengurus dalam pengadaan benih dan pupuk tidak diselewengkan oleh pengurus. Pengelolaan keuangan dan penerimaan bantuan disampaikan secara terbuka oleh pengurus. Pembayaran iuran atau kas dalam menunjang kebutuhan kelompok dilakukan secara terbuka. Anggota gapoktan sepenuhnya mempercayai pengurus kelompok yang tergabung di dalam gapoktan dalam pengelolaan keuangan, pengelolaan sarana produksi, pendistribusian bantuan alat pertanian, dan penyampaian informasi teknologi pertanian.

Tabel 4. Presentase Kepercayaan Berdasarkan Kategori

\begin{tabular}{clccc}
\hline No. & Kategori & Interval Skor & $\begin{array}{c}\text { Frekuensi } \\
\text {-- orang --- }\end{array}$ & $\begin{array}{c}\text { Persentase } \\
\text {---\%--- }\end{array}$ \\
\hline 1. & Sangat Tinggi & $>20$ & 37 & 45 \\
2. & Tinggi & $16-20$ & 39 & 48 \\
3. & Sedang & $11-15$ & 5 & 6 \\
4. & Rendah & $6-10$ & 1 & 1 \\
5. & Sangat Rendah & $<6$ & 0 & 0 \\
\hline & & & $\mathbf{8 2}$ & $\mathbf{1 0 0}$ \\
\hline
\end{tabular}

Sumber: Data primer diolah, 2021

Rasa percaya antara pengurus dan anggota kelompok sudah terbentuk dengan baik sehingga sejauh ini tidak terdapat permasalahan yang berpotensi mengganggu hubungan 
di dalam gapoktan. Rasa percaya yang timbul di dalam diri anggota gapoktan dimulai dengan adanya transparasi dan keterbukaan dari pengurus kepada anggota. Kejujuran pengurus dalam mengelola keuangan gapoktan disampaikan secara terbuka kepada anggota gapoktan. Kedekatan pengurus dan anggota dalam pengelolaan gapoktan juga menimbulkan keyakinan dalam diri anggota terhadap pengurus. Hal ini sesuai pendapat Anggoro (2009) yang menyatakan agar setiap orang dengan kepentingan berbeda dapat bekerja sama untuk mencapai tujuan, juga saling mempercayai satu sama lain untuk mencegah adanya eksploitasi maupun kecurangan dalam hubungan mereka. Tingkat kepercayaan yang tinggi merupakan potensi yang dapat digunakan untuk mengembangkan Gapoktan Ngudi Rukun. Hal ini sejalan dengan pendapat Fanbellisa (2017) yang menyatakan tingginya tingkat kepercayaan dalam suatu kelompok dapat digunakan untuk mendorong bentuk kerjasama yang saling menguntungkan.

Norma. Norma merupakan nilai-nilai, harapan, dan tujuan yang diyakini dan dijalankan bersama oleh sekelompok orang. Norma memiliki peran dalam mengontrol perilaku pengurus dan anggota yang tergabung dalam suatu kelompok. Tingkat presentase norma dapat dilihat pada Tabel 5.

Tabel 5. Presentase Norma Berdasarkan Kategori

\begin{tabular}{clccc}
\hline No. & Kategori & Interval Skor & $\begin{array}{c}\text { Frekuensi } \\
\text {-- orang --- }\end{array}$ & $\begin{array}{c}\text { Persentase } \\
---\%--\end{array}$ \\
\hline 1. & Sangat Tinggi & $>36$ & 23 & 28 \\
2. & Tinggi & $28-36$ & 52 & 64 \\
3. & Sedang & $19-27$ & 5 & 6 \\
4. & Rendah & $10-18$ & 2 & 2 \\
5. & Sangat Rendah & $<10$ & 0 & 0 \\
\hline & & & $\mathbf{8 2}$ & $\mathbf{1 0 0}$ \\
\hline
\end{tabular}

Sumber: Data primer diolah, 2021

Berdasarkan hasil penelitian didapat bahwa tingkat norma dalam Gapoktan Ngudi Rukun termasuk dalam kategori tinggi dengan tingkat presentase $64 \%$. Norma yang ada dalam gapoktan adalah norma tertulis dan norma tidak tertulis yang telah disepakati bersama dalam musyawarah. Norma tertulis adalah aturan tertulis yang berisi peraturan yang wajib ditaati. Norma tidak tertulis adalah aturan tidak tertulis tetapi harus ditaati. Norma yang dibuat oleh anggota dalam gapoktan meliputi aturan dalam melakukan kegiatan usahatani, pemasaran hasil produksi, pengairan, dan ketepatan dalam pengembalian peminjaman modal.

Aturan dalam kegiatan usahatani di Gapoktan Ngudi Rukun yaitu pembagian pupuk bersubsidi melalui kelompok tani masing-masing dengan menyertakan kartu identitas kelompok tani. Petani yang kehilangan kartu identitas kelompok harus menyertakan kartu anggota keluarga sebagai bukti. Aturan dalam pemasaran di Gapoktan Ngudi Rukun yaitu hasil produksi yang dijual ke gudang Gapoktan Ngudi Rukun tidak boleh dicurangi dengan mencampur gabah kering dengan gabah kapak (sekam padi), atau mencampur kacang dengan gulungan tanah liat untuk menambah berat produksi. Petani yang melakukan kecurangan akan memperoleh harga jual lebih rendah dari aturan yang ditetapkan gapoktan. Saat ini harga gabah kering di Gapoktan Ngudi Rukun Rp 5.500,00. Harga beras $\mathrm{Rp} 8.500,00$. Harga kacang tanah $\mathrm{Rp} 10.000,00$.

Aturan dalam pengairan sawah di Gapoktan Ngudi Rukun yaitu pada musim penghujan petani bebas mengairi sawah masing-masing karena air melimpah, pada saat musim kemarau pembagian air dilakukan secara bergilir per patok sawah sesuai jadwal (pagi pukul 04.00 s.d $08.00 \mathrm{WIB}$, siang pukul 08.00 s.d $12.00 \mathrm{WIB}$, sore pukul $12.00 \mathrm{~s} . \mathrm{d}$ 16.00 WIB, malam pukul 16.00 s.d 20.00 WIB). Petani yang melakukan kecurangan dalam pembagian air di musim kemarau mendapat sanksi tidak menerima giliran selama 
2 minggu. Aturan dalam pengembalian peminjaman modal di Gapoktan Ngudi Rukun yaitu petani yang melakukan peminjaman harus mengembalikan uang dengan bunga sebesar $3 \%$ sesuai kesepakatan bersama. Pengembalian uang pinjaman dilakukan saat pertemuan rutin pada hari Rabu Kliwon. Petani yang tidak membayar angsuran pinjaman pada waktu yang ditentukan dikenakan sanksi pembayaran sebesar $5 \%$ dari pinjamannya.

Norma tidak tertulis yang ada di Gapoktan Ngudi Rukun telah melekat pada anggota gapoktan yaitu pada saat pertemuan rutin atau kegiatan lain anggota maupun pengurus harus saling menghormati satu sama lain, saling menghargai pendapat yang diutarakan anggota, dan mengutamakan gotong royong tanpa memilah siapa yang akan ditolong. Pengelolaan kegiatan usahatani di Gapoktan Ngudi Rukun boleh dilakukan secara individu maupun dengan bantuan orang lain. Penggunaan benih yang diberikan oleh gapoktan. Pemeliharaan tanaman pertanian tidak boleh menggunakan zat kimia berbahaya.

Kepatuhan terhadap norma yang diterapkan di Gapoktan Ngudi Rukun sudah dijalankan dengan baik, sejauh ini belum ada anggota Gapoktan Ngudi Rukun yang melakukan pelanggaran berat terhadap norma yang sudah ditetapkan. Apabila terjadi kesalahan maka sanksi diputuskan dalam rapat dengan dihadiri keseluruhan dari anggota gapoktan. Pelanggaran kecil yang ada di Gapoktan Ngudi Rukun yaitu anggota atau pengurus tidak hadir dalam pertemuan rutin tanpa adanya keterangan yang jelas, dan kecurangan petani saat menjual hasil produksi.

\section{Keberlanjutan Gapoktan Ngudi Rukun}

Keberlanjutan yang ada di Gapoktan Ngudi Rukun berada pada kategori sangat tinggi. Tingkat persentase keberlanjutan dapat dilihat pada Tabel 6.

Tabel 6. Presentase Keberlanjutan Berdasarkan Kategori

\begin{tabular}{clccc}
\hline No. & Kategori & Interval Skor & $\begin{array}{c}\text { Frekuensi } \\
\text {-- orang --- }\end{array}$ & $\begin{array}{c}\text { Persentase } \\
-- \text {---- }\end{array}$ \\
\hline 1. & Sangat Tinggi & $>104$ & 77 & 94 \\
2. & Tinggi & $79-104$ & 5 & 6 \\
3. & Sedang & $53-78$ & 0 & 0 \\
4. & Rendah & $27-52$ & 0 & 0 \\
5. & Sangat Rendah & $<27$ & 0 & 0 \\
\hline & & & $\mathbf{8 2}$ & $\mathbf{1 0 0}$
\end{tabular}

Sumber: Data primer diolah, 2021

Berdasarkan hasil penelitian didapat bahwa tingkat keberlanjutan dalam Gapoktan Ngudi Rukun termasuk dalam kategori sangat tinggi dengan tingkat presentase $94 \%$. Tinggginya tingkat keberlanjutan dipengaruhi oleh beberapa komponen yaitu kohesivitas, komitmen, program kerja, dan interdependensi positif. Tingkat kohesivitas yang terdapat di Gapoktan Ngudi Rukun terdiri dari keinginan anggota untuk tetap berada di gapoktan, ketertarikan anggota dengan orang-orang di dalam gapoktan, ketertarikan terhadap program kerja gapoktan, dan ketertarikan terhadap kegiatan gapoktan. Adanya kohesivitas kelompok atau kecenderungan anggota Gapoktan Ngudi Rukun untuk tetap bersama dalam kelompok menunjukkan bahwa gapoktan merupakan hal penting bagi petani. Semakin lama seseorang menjadi anggota kelompok akan memperlihatkan sifat kooperatif dan solidaritas yang tinggi di dalam gapoktan. Kohesivitas kelompok di Gapoktan Ngudi Rukun akan terbentuk apabila dilandasi oleh komitmen yang kuat antar anggota untuk tetap bergabung dalam Gapoktan Ngudi Rukun.

Tingkat komitmen yang ada di Gapoktan Ngudi Rukun berupa kesediaan anggota dalam bekerjasama dan bersungguh-sungguh dalam melaksanakan kegiatan usahatani serta melaksanakan kegiatan yang ada di gapoktan. Keyakinan atau komitmen yang kuat 
antar anggota gapoktan untuk tetap tergabung di dalam kelompok dapat ditingkatkan dan dimanfaatkan untuk mendapat dukungan dengan ikut berpastisipasi dalam pengambilan keputusan. Komitmen merupakan faktor paling kuat dalam menentukan peforma kelompok. Anggota Gapoktan Ngudi Rukun memiliki tujuan bersama dalam pengelolaan usahataninya supaya lebih baik. Keyakinan yang tinggi antar anggota gapoktan memunculkan sikap interdependensi positif (ketergantungan positif) antar anggota gapoktan.

Interdependensi positif Gapoktan Ngudi Rukun dapat dilihat dari ketergantungan anggota terhadap pemberian bantuan tenaga kepada sesama anggota lainnya dalam kegiatan pemeliharaan tanaman dan pengelolaan usahatani, pemberian bantuan pinjaman uang atau sarana produksi dan upah kepada sesama anggota dalam pengelolaan usahatani dan pemeliharaan tanaman. Anggota Gapoktan Ngudi Rukun juga saling berbagi informasi dan bertukar pendapat tentang kegiatan di dalam gapoktan. Dukungan dari sesama anggota mampu menumbuhkan pola kerjasama antar anggota untuk menyelesaikan program kelompok.

Program kerja yang ada di Gapoktan Ngudi Rukun yaitu sebagai unit distribusi/pemasaran, unit cadangan pangan, dan unit sarana produksi pertanian. Unit pemasaran di Gapoktan Ngudi Rukun merupakan proses jual beli hasil pertanian berupa gabah, beras, jagung, kacang tanah, dan ubi kayu. Unit cadangan pangan di Gapoktan Ngudi Rukun merupakan kegiatan menyediakan stok pangan dan mengadakan kegiatan simpan pinjam bagi petani di wilayah kerja gapoktan terutama pada masa paceklik. Unit sarana produksi pertanian di Gapoktan Ngudi Rukun dilakukan dengan pengelolaan terhadap penyediaan pupuk kebutuhan petani melalui RDKK dengan berkoordinasi lewat kelompok tani anggota gapoktan secara terpadu.

Keberlanjutan yang cukup tinggi mengindikasikan bahwa keberadaan Gapoktan Ngudi Rukun telah memberikan manfaat kepada anggotanya dan memiliki kemampuan untuk mengelola gapoktan dan mengembangkan gapoktan secara berkelanjutan. Manfaat Gapoktan Ngudi Rukun bagi anggota gapoktan yaitu sebagai wadah atau tempat bagi anggota dalam memasarkan hasil pertanian, sebagai penyalur bagi anggota dalam pemenuhan kebutuhan pertanian seperti pupuk dan alat pertanian, dan sebagai wadah atau tempat bagi anggota kelompok dalam bertukar informasi mengenai permasalahan pertanian, dan pemecah masalah bagi anggota kelompok. Pengelolaan dan pengembangan Gapoktan Ngudi Rukun berupa pelatihan bagi anggota untuk meningkatkan pengetahuan dan pengalaman anggota dengan pendampingan dari penyuluh pertanian, meningkatkan sarana dan prasarana gapoktan seperti peralatan usahatani, dan meningkatkan jaringan komunikasi antar gapoktan dan anggota atau petani terkait kerjasama serta meningkatkan jaringan kerjasama dengan pihak di luar gapoktan.

\section{Faktor yang Mempengaruhi Keberlanjutan Gapoktan Ngudi Rukun}

Uji validasi menunjukkan bahwa semua instrumen pertanyaan variabel bebas jaringan kerjasama $\left(X_{1}\right)$, kepercayaan $\left(X_{2}\right)$, dan norma $\left(X_{3}\right)$ adalah valid. Nilai cronbach's alpha lebih besar dari 0,6 sehingga seluruh variabel penelitian dinyatakan reliabel atau handal. Hasil uji normalitas Kolmogorov-Smirnov menunjukkan bahwa data berdistribusi normal. Uji asumsi klasik menunjukkan hasil bahwa semua data terbebas dari multikolinearitas, autokorelasi dan heteroskedastisitas. Hasil uji regresi linear berganda dapat dilihat pada Tabel 7.

Berdasarkan Tabel 7 dapat diketahui bahwa hasil uji regresi linear berganda antara variabel jaringan kerjasama $\left(X_{1}\right)$, kepercayaan $\left(X_{2}\right)$, dan norma $\left(X_{3}\right)$ terhadap keberlanjutan gapoktan $(\mathrm{Y})$ adalah sebagai berikut:

$$
Y=1,429+0,161 X_{1}+0,287 X_{2}+0,287 X_{3}+e
$$


Tabel 7. Hasil Uji Regresi Linear Berganda

\begin{tabular}{lccrc}
\hline Variabel & Koefisien & Std. Error & \multicolumn{1}{c}{ T-Value } & Kesimpulan \\
\hline Konstanta & 1.429 & 0.091 & $15.719^{\star * \star}$ & Signifikan \\
X $_{1}$ (Jaringan Kerjasama) & 0.161 & 0.017 & $9.265^{\star \star *}$ & Signifikan \\
X $_{2}$ (Kepercayaan) & 0.287 & 0.017 & $16.552^{\star \star *}$ & Signifikan \\
X $_{3}$ (Norma) & 0.287 & 0.019 & $15.212^{\star \star *}$ & Signifikan \\
\hline F-Statistik (sig.) & 306.764 & $(0.000)$ & & \\
R-Square & 0.922 & & & \\
Adj. R-Square & 0.919 & & & \\
\hline
\end{tabular}

Sumber: Data primer diolah, 2021

Catatan: ${ }^{* * *}$ (sig. pada alpha $\left.1 \%\right)$

Berdasarkan persamaan regresi linear berganda diatas, diperoleh hasil bahwa variabel jaringan kerjasama $\left(X_{1}\right)$, kepercayaan $\left(X_{2}\right)$ dan norma $\left(X_{3}\right)$ berpengaruh terhadap keberlanjutan gapoktan (Y). Nilai konstanta sebesar 1,429 dan bernilai positif artinya jika nilai variabel jaringan kerjasama $\left(X_{1}\right)$, kepercayaan $\left(X_{2}\right)$ dan norma $\left(X_{3}\right)$ memiliki nilai 0 , maka tingkat keberlanjutan gapoktan $(Y)$ nilainya positif sebesar 1,429.

Nilai koefisien regresi variabel jaringan kerjasama $\left(X_{1}\right)$ sebesar 0,161 artinya apabila jaringan kerjasama mengalami kenaikan 1 skor maka tingkat keberlanjutan gapoktan mengalami kenaikan sebesar 0,161 dengan asumsi variabel independen yang lain bernilai tetap. Koefisien bernilai positif artinya terjadi hubungan positif antara jaringan kerjasama dengan keberlanjutan gapoktan. Ketika kerjasama yang terjadi antar anggota Gapoktan Ngudi Rukun meningkat maka keberlanjutan di Gapoktan Ngudi Rukun akan terus terjadi. Kerjasama yang terjadi di Gapoktan Ngudi Rukun terletak pada kegiatan pengolahan lahan yaitu kegiatan pada saat mencangkul dan membajak sawah, menanam padi, dan memanen hasil pertanian. Tingginya tingkat kerjasama yang terjalin antar anggota gapoktan akan mempertahankan keberlanjutan di Gapoktan Ngudi Rukun.

Nilai koefisien regresi variabel kepercayaan $\left(X_{2}\right)$ sebesar 0,287 artinya apabila kepercayaan $\left(\mathrm{X}_{2}\right)$ mengalami kenaikan 1 skor maka tingkat keberlanjutan gapoktan $(\mathrm{Y})$ mengalami kenaikan sebesar 0,287 dengan asumsi variabel independen yang lain bernilai tetap. Koefisien bernilai positif artinya terjadi hubungan positif antara kepercayaan dengan keberlanjutan gapoktan. Ketika rasa saling percaya yang dimiliki anggota Gapoktan Ngudi Rukun meningkat maka keberlanjutan di Gapoktan Ngudi Rukun akan terus terjadi. Kepercayaan yang ada di Gapoktan Ngudi Rukun berupa kepercayaan antar anggota dengan pengurus gapoktan. Tingkat kepercayaan yang melekat di dalam diri anggota gapoktan muncul dengan adanya sikap keterbukaan dari pengurus dalam menyampaikan pengelolaan gapoktan, pengelolaan keuangan dan pengelolaan bantuan dari pemerintah untuk kelompok tani yang tergabung di Gapoktan Ngudi Rukun. Tingginya rasa saling percaya antara sesama anggota dan pengurus gapoktan akan mempertahankan keberlanjutan di Gapoktan Ngudi Rukun.

Nilai koefisien regresi variabel norma $\left(X_{3}\right)$ sebesar 0,287 artinya apabila norma $\left(X_{3}\right)$ mengalami kenaikan 1 skor maka tingkat keberlanjutan gapoktan $(Y)$ mengalami kenaikan sebesar 0,287 dengan asumsi variabel independen yang lain bernilai tetap. Koefisien bernilai positif artinya terjadi hubungan positif antara norma dengan keberlanjutan gapoktan. Ketika kepatuhan anggota gapoktan terhadap norma yang berlaku di Gapoktan Ngudi Rukun meningkat maka keberlanjutan Gapoktan Ngudi Rukun akan terus terjadi. Kepatuhan terhadap norma ditunjukkan oleh sikap anggota dan pengurus gapoktan dalam mentaati aturan yang telah di sepakati bersama. Aturan yang ada di Gapoktan Ngudi Rukun berupa aturan dalam penyediaan sarana produksi berupa pembagian pupuk bersubsidi dilakukan dengan penyertaan kartu identitas kelompok tani, pemasaran hasil pertanian tidak boleh dicurangi dengan mengurangi kualitas produk, dan pembagian air di musim kemarau dilakukan secara bergilir. Tinggginya tingkat kepatuhan yang ditunjukkan oleh anggota gapoktan akan mempertahankan keberlanjutan di Gapoktan Ngudi Rukun. 


\section{Uji-F}

Berdasarkan hasil analisis dapat diketahui bahwa nilai $F$ hitung sebesar 306,764 dengan nilai sig. sebesar 0,000 . Tingkat signifikansi yang digunakan dalam penelitian adalah $\alpha=0,05$. Nilai sig. 0,000 $\leq 0,05$ maka Ho ditolak dan Hi diterima, artinya variabel bebas secara serempak mempengaruhi variabel terikat. Hal ini berarti bahwa variabel jaringan kerjasama, kepercayaan dan norma yang terjadi antara kelompok tani secara serempak mempengaruhi keberlanjutan Gabungan Kelompok Tani Ngudi Rukun di Desa Doho Kecamatan Girimarto. Hal ini sesuai dengan penelitian terdahulu yang dilakukan oleh Thobias et al. (2013) yang menyatakan bahwa Ho telah ditolak dan Hi diterima atau terdapat hubungan yang sangat kuat antara modal sosial dengan perilaku pada objek yang diteliti. Hal ini didukung oleh penelitian Fanbellisa (2017) yang menyatakan bahwa modal sosial yang terdiri dari network, trust, norm berpengaruh secara nyata terhadap keberlanjutan gapoktan.

Modal sosial dalam penelitian ini terdiri dari jaringan kerjasama, kepercayaan dan norma. Ketiga faktor tersebut saling berhubungan dalam menentukan keberlanjutan gapoktan. Jaringan kerjasama yang tinggi akan meningkatkan jaringan informasi diantara anggota kelompok. Informasi di Gapoktan Ngudi Rukun diperoleh dari hasil penyuluhan yang diberikan oleh tim penyuluh pertanian salah satunya yaitu inovasi dalam pembuatan pupuk cair menggunakan urin kelinci. Informasi yang diterima oleh anggota kelompok akan memberikan peluang dalam mengembangkan dan meningkatkan kualitas anggota Gapoktan Ngudi Rukun serta memberikan pengaruh terhadap keberlanjutan gapoktan. Tingkat jaringan kerjasama yang ada di Gapoktan Ngudi Rukun dapat dilihat dari kerjasama antar anggota dalam kegiatan pengolahan lahan yaitu pada saat mencangkul dan membajak sawah, menanam padi, dan memanen hasil pertanian. Anggota kelompok saling membantu satu sama lain.

Kekompakan anggota dalam pengelolaan usahatani mencerminkan kerjasama yang di bangun berdasarkan hubungan interpersonal diantara anggota gapoktan. Kerjasama yang terjalin baik akan menumbuhkan rasa saling percaya antar anggota di dalam kelompok. Kepercayaan anggota muncul dengaan adanya sikap keterbukaan pengurus kelompok dalam menyampaikan rincian keuangan, bantuan dan kedekatan pengurus dengan anggota menimbulkan rasa ingin selalu bersama di dalam kelompok. Kepercayaan yang tertanan pada anggota kelompok menimbulkan keyakinan di dalam diri anggota untuk memajukan Gapoktan Ngudi Rukun dengan mematuhi norma yang telah disepakati bersama. Aturan di Gapoktan Ngudi Rukun tidak lepas dari kepatuhan anggota terhadap kegiatan pengelolaan lahan seperti pembagian air sawah saat musim kemarau.

\section{Koefisisen Determinasi (Adjusted R-Square)}

Hasil penelitian menunjukkan bahwa nilai Adjusted $R$-Square sebesar 0,919. Nilai tersebut menunjukkan bahwa variabel bebas $\left(X_{1}, X_{2}, X_{3}\right)$ yang diajukan mampu menjelaskan variabel $(Y)$ sebesar $91,9 \%$. Hal tersebut menunjukkan bahwa 91,9\% perubahan terhadap variabel terikat $(Y)$ disebabkan oleh perubahan variabel bebas $\left(X_{1}\right.$, $\mathrm{X}_{2}, \mathrm{X}_{3}$ ) secara bersama-sama, sisanya 8,1\% dijelaskan oleh faktor lain diluar model yang diajukan peneliti seperti pengetahuan anggota, sikap anggota, keterampilan anggota, pengalaman anggota dalam bertani dan partisipasi dari anggota gapoktan. Hal ini berarti bahwa keberlanjutan Gapoktan Ngudi Rukun dipengaruhi oleh modal sosial (jaringan kerjasama, kepercayaan, dan norma) sebesar $91,9 \%$.

\section{Uji-t}

Berdasarkan hasil analisis dapat diketahui bahwa nilai sig. dari tiga variabel bebas sebesar 0,000 . Nilai sig. $0,000 \leq 0,05$ maka $\mathrm{HO}$ ditolak, artinya variabel bebas secara parsial mempengaruhi variabel terikat. Hal ini membuktikan bahwa variabel bebas yang terdiri dari jaringan kerjasama, kepercayaan dan norma yang terdapat diantara anggota kelompok tani berpengaruh secara parsial terhadap keberlanjutan Gabungan Kelompok Tani Ngudi Rukun di Desa Doho Kecamatan Girimarto Kabupaten Wonogiri. Hal ini sesuai 
dengan penelitian yang dilakukan Anggoro (2009) yang menyatakan pengaruh modal sosial terhadap ketahanan usaha signifikan, atau dengan kata lain adanya pengaruh yang signifikan antara variabel prediktor terhadap variabel kriterium. Hal ini juga sesuai dengan penelitian yang dilakukan Munawaroh (2017) yang menyatakan dengan hasil nilai sig. $0,000 \leq 0,05$ maka dapat dikatakan positif dan signifikan, berarti ada pengaruh yang positif antara modal sosial terhadap peningkatan kesejahteraan yang diteliti.

\section{Pengaruh Kepercayaan terhadap Gapoktan Ngudi Rukun}

Berdasarkan hasil analisis dapat diketahui bahwa nilai sig. dari variabel kepercayaan $\left(X_{2}\right)$ sebesar 0,000 . Nilai sig. $0,000 \leq 0,05$ maka variabel kepercayaan yang terjalin antar anggota kelompok tani berpengaruh secara parsial terhadap keberlanjutan Gabungan Kelompok Tani Ngudi Rukun di Desa Doho, Kecamatan Girimarto, Kabupaten Wonogiri. Hasil analisis modal sosial di Gapoktan Ngudi Rukun berupa tingkat kepercayaan tergolong dalam kategori tinggi dengan tingkat presentase $48 \%$. Dilihat dari aspek pengaruhnya menunjukkan bahwa kepercayaan berpengaruh positif terhadap keberlanjutan gapoktan, yang berarti ketika rasa saling percaya yang dimiliki anggota Gapoktan Ngudi Rukun meningkat maka keberlanjutan di Gapoktan Ngudi Rukun akan terus terjadi. Kepercayaan yang ada di Gapoktan Ngudi Rukun berupa kepercayaan antar anggota dengan pengurus gapoktan. Tingkat kepercayaan yang melekat di dalam diri anggota gapoktan muncul dengan adanya sikap keterbukaan dari pengurus dalam menyampaikan pengelolaan gapoktan, pengelolaan keuangan dan pengelolaan bantuan dari pemerintah untuk kelompok tani yang tergabung dalam Gapoktan Ngudi Rukun di Desa Doho, Kecamatan Girimarto.

\section{Pengaruh Norma Terhadap Gapoktan Ngudi Rukun}

Berdasarkan hasil analisis dapat diketahui bahwa nilai sig. dari variabel norma $\left(\mathrm{X}_{3}\right)$ sebesar 0,000 . Nilai sig. $0,000 \leq 0,05$ maka variabel norma yang telah disepakati bersama antar anggota kelompok tani berpengaruh secara parsial terhadap keberlanjutan Gabungan Kelompok Tani Ngudi Rukun di Desa Doho, Kecamatan Girimarto, Kabupaten Wonogiri. Hasil analisis modal sosial di Gapoktan Ngudi Rukun berupa norma atau aturan yang telah disepakati bersama tergolong dalam kategori tinggi dengan tingkat presentase 64\%. Dilihat dari aspek pengaruhnya menunjukkan bahwa norma yang berlaku berpengaruh positif terhadap keberlanjutan gapoktan, yang berarti ketika norma atau aturan yang diterapkan ditaati, dipatuhi dan dijalankan sesuai semestinya oleh semua anggota yang tergabung di dalam Gapoktan Ngudi Rukun maka akan mempertahankan keberlanjutan Gapoktan. Aturan yang ada di Gapoktan Ngudi Rukun berupa aturan dalam penyediaan sarana produksi berupa pembagian pupuk bersubsidi dilakukan dengan penyertaan kartu identitas kelompok tani, pemasaran hasil pertanian tidak boleh dicurangi dengan mengurangi kualitas produk, dan pembagian air di musim kemarau dilakukan secara bergilir.

\section{SIMPULAN}

Analisis modal sosial yang ada di Gapoktan Ngudi Rukun terdiri dari tiga kategori yaitu jaringan kerjasama, kepercayaan dan norma. Modal sosial yang berada di Gapoktan Ngudi Rukun tergolong dalam kategori tinggi dengan presentase jaringan kerjasama $60 \%$, kepercayaan $48 \%$ dan norma 64\%. Analisis tingkat keberlanjutan di Gapoktan Ngudi Rukun termasuk dalam kategori sangat tinggi dengan tingkat presentase $94 \%$ yang berarti gapoktan telah memberikan manfaat kepada anggotanya dan memiliki kemampuan untuk mengelola dan mengembangkan gapoktan secara berkelanjutan. Analisis pengaruh modal sosial menunjukkan bahwa terdapat pengaruh yang positif dan signifikan antara modal sosial terhadap keberlanjutan Gabungan Kelompok Tani Ngudi Rukun sebesar 91,9\%. Semakin meningkat modal sosial yang ada di Gabungan Kelompok Tani Ngudi Rukun, akan semakin meningkatkan pula keberlanjutan Gabungan 
Kelompok Tani Ngudi Rukun yang ada di Desa Doho, Kecamatan Girimarto, Kabupaten Wonogiri.

Modal sosial yang terdapat dalam gapoktan termasuk dalam kategori tinggi untuk itu perlu dipertahankan dalam mengembangkan usaha ekonomi produktif sesuai dengan potensi yang dimiliki gapoktan. Selain itu, kinerja pengurus gapoktan dapat ditingkatkan lagi dalam pengelolaan kelengkapan sarana dan prasarana gapoktan, sehingga mampu memfasilitasi kebutuhan petani dalam mengembangkan usahataninya.

\section{DAFTAR PUSTAKA}

Anggoro, A. D. (2009). Pengaruh Modal Sosial, Pemberdayaan Masyarakat, dan Bantuan Sosial terhadap Ketahanan Pangan. Program Sarjana Universitas Sebelas Maret. Surakarta.

Barki, K. (2017). Pengaruh Modal Sosial terhadap Tingkat Adopsi Inovasi Padi Organik pada Anggota Kelompok Tani Paguyuban Al-Barokah, Desa Ketapang, Kecamatan Susukan, Kabupaten Semarang. J. Agromedia. 35(2): 55 - 63.

Bulu, Y.G. (2010). Kajian Pengaruh Modal Sosial dan Keterdedahan Informasi Inovasi terhadap Tingkat Adopsi Inovasi Jagung Dilahan Sawah dan Lahan Kering. Disertasi Universitas Gadjah Mada, Yogjakarta. (Tidak dipublikasikan).

Damayanti, L. (2013). Faktor-faktor yang mempengaruhi produksi, pendapatan dan kesempatan kerja pada usaha tani padi sawah di daerah irigasi parigi moutong. SEPA: Jurnal Sosial Ekonomi Pertanian dan Agribisnis, 9(2): 249-259.

Fadhillah, L. E. (2018). Pengaruh Perilaku Petani Padi terhadap Pengggunaan Benih Padi Bersubsidi di Desa Tlogoweru, Kecamatan Guntur, Kabupaten Demak. Skripsi Program Sarjana Universitas Diponegoro, Semarang.

Fanbellisa, S. (2017). Pengaruh Modal Sosial terhadap Keberlanjutann Gabungan Kelompok TanimSumber Mulyo di Desa Banjaran Kecamatan Bangsri, Kabupaten Jepara. Skripsi Program Sarjana Universitas Diponegoro. Semarang.

Hayati, M., Elfiana., dan Martina. (2017). Peranan Sektor Pertanian dalam Pembangunan Wilayah Kabupaten Bireuen Provinsi Aceh. J. S. Pertanian. 1(3): 213 - 222.

Mawardi, M. (2007). Peranan sosial kapital dalam pemberdayaan masyarakat. J. Pembangunan Majalah Islam.

Munawaroh, S. T. (2017). Pengaruh Modal Sosial terhadap Peningkatan Kesejahteraan Penambang Pasir di Desa Sadangwetan Kecamatan Sadang Kabupaten Kebumen. Skripsi Program Sarjana Universitas Muhammadiyah Purworejo. Purworejo.

Tangio, N. S. (2021). Role Of Social Capital Community Business Development Process Agroindustry Palm Sugar Protected Areas In The Forest Buffer. Jambura Agribusiness Journal, 2(2): 55-65.

Thobias, E., A. K. Tungka., dan J. J. Rogahang. (2013). Pengaruh Modal Sosial terhadap Perilaku Kewirausahaan (Suatu Studi pada Pelaku Usaha Mikro Kecil Menengah di Kecamatan Kabaruan Kabupaten Kepulauan Talaud). J. Acta Diurna, 1 - 12. 